\title{
Re-Evaluation of Chemotherapeutic Potential of Pyoktanin Blue
}

\author{
Hiroshi Sakagami ${ }^{1, *(1)}$, Toshiko Furukawa ${ }^{2}$, Keitaro Satoh ${ }^{3}$, Shigeru Amano ${ }^{1}$, Yosuke Iijima ${ }^{4}$, \\ Takuro Koshikawa ${ }^{5}$, Daisuke Asai ${ }^{5,6}{ }^{\mathbb{D}}$, Kunihiko Fukuchi ${ }^{7}$, Hiromu Takemura ${ }^{5}$, Taisei Kanamoto ${ }^{6}$ \\ and Satoshi Yokose ${ }^{2}$
}

1 Research Institute of Odontology (M-RIO), Meikai University, 1-1 Keyakidai, Sakado, Saitama 350-0283, Japan; shigerua@dent.meikai.ac.jp

2 Division of Endodontics and Operative Dentistry, School of Dentistry, Meikai University, 1-1 Keyakidai, Sakado, Saitama 350-0283, Japan; to-ko@dent.meikai.ac.jp (T.F.); s-yokose@dent.meikai.ac.jp (S.Y.)

3 Division of Pharmacology, Meikai University School of Dentistry, 1-1 Keyakidai, Sakado, Saitama 350-0283, Japan; k-satoh@dent.meikai.ac.jp

4 Department of Oral and Maxillofacial Surgery, Saitama Medical Center, Saitama 350-8550, Japan; yoiijima@saitama-med.ac.jp

5 Department of Microbiology, St. Marianna University School of Medicine, 2-16-1 Sugao, Miyamae-ku, Kawasaki 216-8511, Japan; takuro.koshikawa@marianna-u.ac.jp (T.K.); asai@marianna-u.ac.jp (D.A.); takeh@marianna-u.ac.jp (H.T.)

6 Laboratory of Microbiology, Showa Pharmaceutical University, 3-3165 Higashi-Tamagawagakuen, Machida, Tokyo 194-8543, Japan; kanamoto@ac.shoyaku.ac.jp

7 Graduate School of Health Sciences, Showa University, 1-5-8 Hatanodai, Shinagawa-ku, Tokyo 142-8555, Japan; kfukuchi@med.showa-u.ac.jp

* Correspondence: sakagami@dent.meikai.ac.jp; Tel.: +81-04-9279-2758

Citation: Sakagami, H.; Furukawa, T.; Satoh, K.; Amano, S.; Iijima, Y.; Koshikawa, T.; Asai, D.; Fukuchi, K.; Takemura, H.; Kanamoto, T.; et al. Re-Evaluation of Chemotherapeutic Potential of Pyoktanin Blue. Medicines 2021, 8, 33. https://doi.org/10.3390/ medicines 8070033

Academic Editor: Makoto Endo

Received: 17 May 2021

Accepted: 15 June 2021

Published: 22 June 2021

Publisher's Note: MDPI stays neutral with regard to jurisdictional claims in published maps and institutional affiliations.

Copyright: (C) 2021 by the authors. Licensee MDPI, Basel, Switzerland. This article is an open access article distributed under the terms and conditions of the Creative Commons Attribution (CC BY) license (https:/ / creativecommons.org/licenses/by/ $4.0 /)$.
Abstract: Background: Pyoktanin blue (PB) is used for staining tissues and cells, and it is applied in photodynamic therapy due to its potent bactericidal activity. However, clinical application of $\mathrm{PB}$ as an antiviral and antitumor agent has been limited due to its potent toxicity. For clinical application, the antitumor and antiviral activity as well as the neurotoxicity of PB were re-evaluated with a chemotherapeutic index. Methods: Tumor-specificity (TS) was determined by the ratio of $\mathrm{CC}_{50}$ against normal oral cells/oral squamous cell carcinoma (OSCC); neurotoxicity by that of normal oral/neuronal cells; antiviral activity by that of mock-infected/virus-infected cells; and potency-selectivity expression (PSE) by dividing TS by $\mathrm{CC}_{50}$ (OSCC). Results: Antitumor activity of PB (assessed by TS and PSE) was comparable with that of DXR and much higher than that of 5-FU and melphalan. PB induced caspase-3 activation and subG1 cell accumulation in an OSCC cell line (Ca9-22). PB and anticancer drugs showed comparable cytotoxicity against both neuronal cells and OSCC cell lines. PB showed no detectable anti-HIV/HSV activity, in contrast to reverse transferase inhibitors, sulfated glucans, and alkaline extract of leaves of S.P. Conclusions: PB showed first-class anticancer activity and neurotoxicity, suggesting the importance of establishing the safe treatment schedule.

Keywords: pyoktanin; anticancer activity; oral cancer; apoptosis; chemotherapeutic index; caspase-3; subG1 accumulation; anti-HIV; anti-HSV

\section{Introduction}

Pyoktanin blue (PB), 4-\{bis [4-(dimethylamino) phenyl] methylidene\}- $N, N$-dimethylcy clohexa-2,5-dien-1-iminium chloride (also known as crystal violet, methyl violet, or gentian violet) is a cationic dye used as a histological stain and visualization [1-4] and in Gram's method of classifying bacteria [5] (Figure 1). A paper on the selective bactericidal action of PB dates back to 1912 [6]. PB showed potent fungicidal activity when administered topically, alone or in combination with oral antifungal drugs [7]. Photodynamic therapy with PB effectively eliminated enterococcus faecalis [8] and inhibited biofilm formation [9,10]. PB has been applied to the Valiant ${ }^{\circledR}$ thoracic stent graft system prior to insertion to prevent 
infection [11]. As one antibacterial mechanism, malfunction of TRX2 by adduct formation with thioredoxin reductase 2 (TRX2) has been suggested [12].<smiles>CN(C)c1ccc(C(=C2C=CC(=[N+](C)C)C=C2)c2ccc(N(C)C)cc2)cc1</smiles>

- Utilized as staining tissues or cells

- Antiseptic

- Antibacterial

- Applicable to photodynamic therapy

$\mathrm{Cl}^{-}$

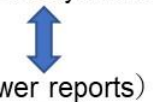

(Fewer reports)

- Antiviral $\Rightarrow$ Relative potency vs. antiviral agents?

- Antitumor $\Rightarrow$ Relative potency vs. anticancer agents? Side effects?

Figure 1. Structure of pyoktanin blue (PB) and design of the present study.

On the other hand, publications on the antiviral activity and antitumor activity of PB have been fewer compared with publications on its antibacterial activity. PB showed antiviral activity against Nipah, Hendra virus, their pseudotypes, vesicular stomatitis virus, and human parainfluenza virus type 3, except influenza A virus [13], while another group reported the opposite result, finding that $\mathrm{PB}$ inactivated the influenza A virus [14]. As for anticancer activity, PB induced cell death in oral precancerous cells through ROS production, suppressed the progression of DMBA-induced oral precancerous lesions [15], and prompted apoptosis in a human breast cancer cell line [16]. Although many anticancer drugs induce adverse effects, such as oral mucositis, peripheral neurotoxicity, and extravasation at the injection site [17], most of previous studies of PB do not present information of its chemotherapeutic index (safety margin), possible adverse effects, and comparative performance against appropriate antiviral and antitumor agents. In the present study, antitumor activity, neurotoxicity, and antiviral activity of PB were re-evaluated by chemotherapeutic indices and in comparison with appropriate positive controls in order to establish the most effective administration schedule of PB.

\section{Materials and Methods}

\subsection{Materials}

Pyoktanin blue (PB) $(0.2 \%$ solution) (MW408) was purchased from Honzo Pharmaceutical Co., Ltd. (Nagoya, Japan); Dulbecco's modified Eagle's medium (DMEM) from GIBCO BRL (Grand Island, NY, USA); fetal bovine serum (FBS), doxorubicin (DXR), 3(4,5-dimethylthiazol-2-yl)-2,5-diphenyltetrazolium bromide (MTT), ribonuclease A, azidothymidine (AZT), 2', 3'-dideoxycytidine (ddC) from Sigma-Aldrich Inc. (St. Louis, MO, USA); dimethyl sulfoxide (DMSO), actinomycin D, dextran sulfate (DS) (5 kDa), $4 \%$ paraformaldehyde phosphate buffer solution, propidium iodide from FUJIFILM Wako Chem. (Osaka, Japan); 5-fluorouracil (5-FU) from Kyowa (Tokyo, Japan); curdlan sulfate (79 kDa) (Ajinomoto Co., Inc., Tokyo, Japan); Nonidet-40 (NP-40) from Nakalai Tesque Inc. (Kyoto, Japan); 96-well plates from TPP (Techno Plastic Products AG) (Trasadingen, Switzerland); and $100 \mathrm{~mm}$ dishes from True Line (Nippon Genetics Co., Ltd., Tokyo, Japan).

\subsection{Cell Culture}

Human oral squamous cell carcinoma (OSCC) cell lines (Ca9-22 (derived from gingiva), HSC-2, HSC-3, HSC-4 (derived from tongue)), rat adrenal pheochromocytoma cell line (PC12), human neuroblastoma cell line (SH-SY5Y), and rat Schwann cell line (LY-PPB6) (purchased from RIKEN Cell Bank, Tsukuba, Japan) were cultured at $37^{\circ} \mathrm{C}$ in DMEM supplemented with $10 \%$ heat $\left(56^{\circ} \mathrm{C}, 30 \mathrm{~min}\right)$-inactivated $\mathrm{FBS}, 100 \mathrm{U} / \mathrm{mL}$ penicillin $\mathrm{G}$, and $100 \mu \mathrm{g} / \mathrm{mL}$ streptomycin sulfate under a humidified $5 \% \mathrm{CO}_{2}$ atmosphere.

We previously established human gingival fibroblast (HGF), periodontal ligament fibroblast (HPLF), and pulp cell (HPC) from the first premolar extracted tooth and periodontal tissues of a twelve-year-old girl, according to the guideline of Institutional Board 
of Meikai University Ethic Committee (No. A0808) [18]. Since these cells have a limited lifespan [18], cells at 10-18 population doubling level (PDL) were used in the present study.

Differentiated PC12 cells were prepared by the "overlay method", as described previously [19]. In brief, PC12 cells were cultured in the serum-free DMEM supplemented with $50 \mathrm{ng} / \mathrm{mL}$ NGF, and overlayed with fresh NGF solution at Day 3. The Day 6 cells with extended neurites were used for the experiment.

\subsection{Assay for Cytotoxic Activity}

Cells were detached by trypsin, inoculated at $2 \times 10^{3}$ cells $/ 0.1 \mathrm{~mL}$ in a 96-microwell plate and incubated for $48 \mathrm{~h}$ to recover from the trypsin damage and to secure complete cell attachment. Microscopical observation revealed that at this time, the OSCC cells occupied approximately $20-30 \%$ of the bottom of each well. Then, the culture medium was replaced with $0.1 \mathrm{~mL}$ of fresh medium containing different concentrations of test compounds (PB $(0.2,0.4,0.8,1.5,3,6,12$, and $25 \mu \mathrm{M})$; DXR $(0.08,0.16,0.31,0.63,1.25$, 2.5, 5, and $10 \mu \mathrm{M})$; 5-FU $(8,16,31,63,125,250,500$, and $1000 \mu \mathrm{M})$; melphalan $(2,4,8$, $16,31,63,125,250 \mu \mathrm{M})$; and vehicle (DMSO) $(0.008,0.016,0.031,0.063,0.125,0.25,0.5$, and $1 \%)$ ). Cells were then incubated further for $48 \mathrm{~h}$ and the relative viable cell number was then determined by the MTT method, as described previously [20]. In brief, cells were incubated for $2 \mathrm{~h}$ with $0.2 \mathrm{mg} / \mathrm{mL}$ MTT, and formazan precipitate was dissolved with $100 \mu \mathrm{L}$ DMSO; the absorbance of the cell lysate at $560 \mathrm{~nm}$ (that reflects the relative viable cell number) was then determined using a microplate reader (Infinite F50R; TECAN, Männedorf, Switzerland). Cytotoxicity caused by the vehicle (DMSO) was subtracted. The concentration of compound that reduced the viable cell number by $50 \%\left(\mathrm{CC}_{50}\right)$ was determined from the dose-response curve, and the mean value of $\mathrm{CC}_{50}$ for each cell type was calculated from triplicate assays. To test the reproducibility, cytotoxicity assays were repeated three times.

The absorbance value at $560 \mathrm{~nm}$ of control OSCC cells $96 \mathrm{~h}$ after inoculation reached approximately 1.0, within the range of linearity of the absorbance. We used the $48 \mathrm{~h}$ treatment time to make the cells go around the cell cycle twice for the calculation of $\mathrm{CC}_{50}$ value. When cytostatic agents such as 5-FU are used, this consideration is necessary.

\subsection{Calculation of Tumor-Specificity Index (TS)}

TS was calculated using the following equation: $\mathrm{TS}=$ mean $\mathrm{CC}_{50}$ against three normal human oral mesenchymal cells (HGF + HPLF + HPC)/mean CC $_{50}$ against four OSCC cell lines (Ca9-22 + HSC-2 + HSC-3 + HSC-4), as shown by D/B in Table 1. Since both Ca9-22 and HGF cells were derived from gingival tissue [21], the relative sensitivity of these cells was also compared (as shown by C/A in Table 1).

\subsection{Calculation of Potency-Selectivity Expression (PSE)}

Parameters that reflect both tumor-specificity (TS) and cytotoxicity against tumor cells (reciprocal of $\mathrm{CC}_{50}$ value) are useful for the treatment of cancer patients. PSE was calculated using the following equation: PSE $=100 \times \mathrm{TS} / \mathrm{CC}_{50}$ (tumor cells) $\left(100 \times \mathrm{D} / \mathrm{B}^{2}\right)$ (three normal oral cells vs. four OSCC cell lines) and $100 \times \mathrm{C} / \mathrm{A}^{2}$ (HGF vs. Ca9-22) (Table 1).

\subsection{Cell Cycle Analysis}

Treated and untreated Ca9-22 cells (approximately $10^{6}$ cells) were harvested, fixed with $1 \%$ paraformaldehyde, treated with $0.2 \mathrm{mg} / \mathrm{mL}$ RNase A (preheated for $10 \mathrm{~min}$ at $100{ }^{\circ} \mathrm{C}$ to inactivate DNase), stained for $15 \mathrm{~min}$ with $0.01 \%$ propidium iodide in the presence of $0.01 \%$ NP-40 to prevent cell aggregation, filtered through Falcon ${ }^{\circledR}$ cell strainers $(40 \mu \mathrm{M})$ (Corning, NY, USA), subjected to cell sorting (SH800 Series; SONY Imaging Products and Solutions Inc., Kanagawa, Japan), and then analyzed with Cell Sorter Software version 2.1.2. (SONY Imaging Products and Solutions Inc.), as described previously [20]. 
Table 1. TS and PSE values of PB and anticancer drugs, determined by three independent experiments.

\begin{tabular}{|c|c|c|c|c|c|c|c|c|c|c|c|c|c|}
\hline & \multicolumn{9}{|c|}{$\mathrm{CC}_{50}(\mu \mathrm{M})$} & & & & \\
\hline & \multicolumn{5}{|c|}{ Human Oral Squamous Carcinoma Cell } & \multicolumn{4}{|c|}{ Human Normal Oral Cells } & \multirow{2}{*}{\multicolumn{2}{|c|}{ TS }} & \multirow{2}{*}{\multicolumn{2}{|c|}{ PSE }} \\
\hline & Ca9-22 & HSC-2 & HSC-3 & HSC-4 & Mean & HGF & HPLF & HPC & Mean & & & & \\
\hline & A & & & & B & $\mathrm{C}$ & & & $\mathbf{D}$ & $\mathrm{D} / \mathrm{B}$ & C/A & $100 \mathrm{D} / \mathrm{B}^{2}$ & $100 \mathrm{C} / \mathrm{A}^{2}$ \\
\hline PB & 0.30 & 0.26 & 0.81 & 0.46 & 0.46 & 12.1 & 10.5 & 19.6 & 14.1 & 30.8 & 40.0 & 6722 & 13,197 \\
\hline DXR & 0.41 & 0.16 & 0.43 & 0.20 & 0.30 & 10.0 & 7.1 & 10.0 & 9.0 & 30.0 & 24.4 & 9986 & 5930 \\
\hline 5-FU & 124 & 109 & 1000 & 73 & 326 & 1000 & 100 & 1000 & 1000 & 3.1 & 8.1 & 1 & 7 \\
\hline Mel & 27 & 12 & 19 & 9 & 17 & 200 & 200 & 200 & 200 & 11.8 & 7.4 & 70 & 27 \\
\hline $\mathrm{PB}$ & 0.19 & 0.19 & 0.54 & 0.23 & 0.29 & 8.3 & 7.6 & 7.2 & 7.7 & 26.6 & 43.5 & 9203 & 22,734 \\
\hline DXR & 0.45 & 0.18 & 0.27 & 0.09 & 0.25 & 10.0 & 10.0 & 10.0 & 10.0 & 40.7 & 22.1 & 16,525 & 4902 \\
\hline 5-FU & 314 & 1000 & 20 & 9 & 336 & 1000 & 1000 & 1000 & 1000 & 3.0 & 3.2 & 1 & 1 \\
\hline Mel & 39 & 11 & 18 & 5 & 18 & 200 & 200 & 155 & 185 & 10.3 & 5.2 & 57 & 13 \\
\hline $\mathrm{PB}$ & 0.19 & 0.24 & 0.61 & 0.23 & 0.32 & 7.3 & 6.4 & 10.4 & 8.0 & 25.4 & 37.9 & 8067 & 19,850 \\
\hline DXR & 0.33 & 0.34 & 0.38 & 0.14 & 0.30 & 10.0 & 10.0 & 10.0 & 10.0 & 33.5 & 29.9 & 11,192 & 8964 \\
\hline 5-FU & 136 & 1000 & 1000 & 31 & 542 & 1000 & 1000 & 1000 & 1000 & 1.8 & 7.4 & 0.3 & 5 \\
\hline Mel & 38 & 13 & 23 & 6 & 20 & 200 & 200 & 165 & 188 & 9.4 & 5.2 & 46 & 14 \\
\hline
\end{tabular}

The $50 \%$ cytotoxic concentration $\left(\mathrm{CC}_{50}\right)$ was determined by Figure 2 . TS (D/B) was determined by dividing [ $\left(\mathrm{CC}_{50}(\mathrm{HGF})+\mathrm{CC} \mathrm{C}_{50}(\mathrm{HPLF})\right.$ $\left.\left.+\mathrm{CC}_{50}(\mathrm{HPC})\right) / 3\right]$ by $\left[\left(\mathrm{CC}_{50}(\mathrm{Ca} 9-22)+\mathrm{CC}_{50}(\mathrm{HSC}-2)+\mathrm{CC}_{50}(\mathrm{HSC}-3)+\mathrm{CC}_{50}(\mathrm{HSC}-4)\right) / 4\right]$. TS (C/A) was determined by dividing $\mathrm{CC}_{50}$ (HGF) by $\mathrm{CC}_{50}$ (Ca9-22). PSE was determined by dividing TS (D/B or C/A) by B or A and then multiplying by 100. PB, pyoktanin blue; Mel. melphalan.

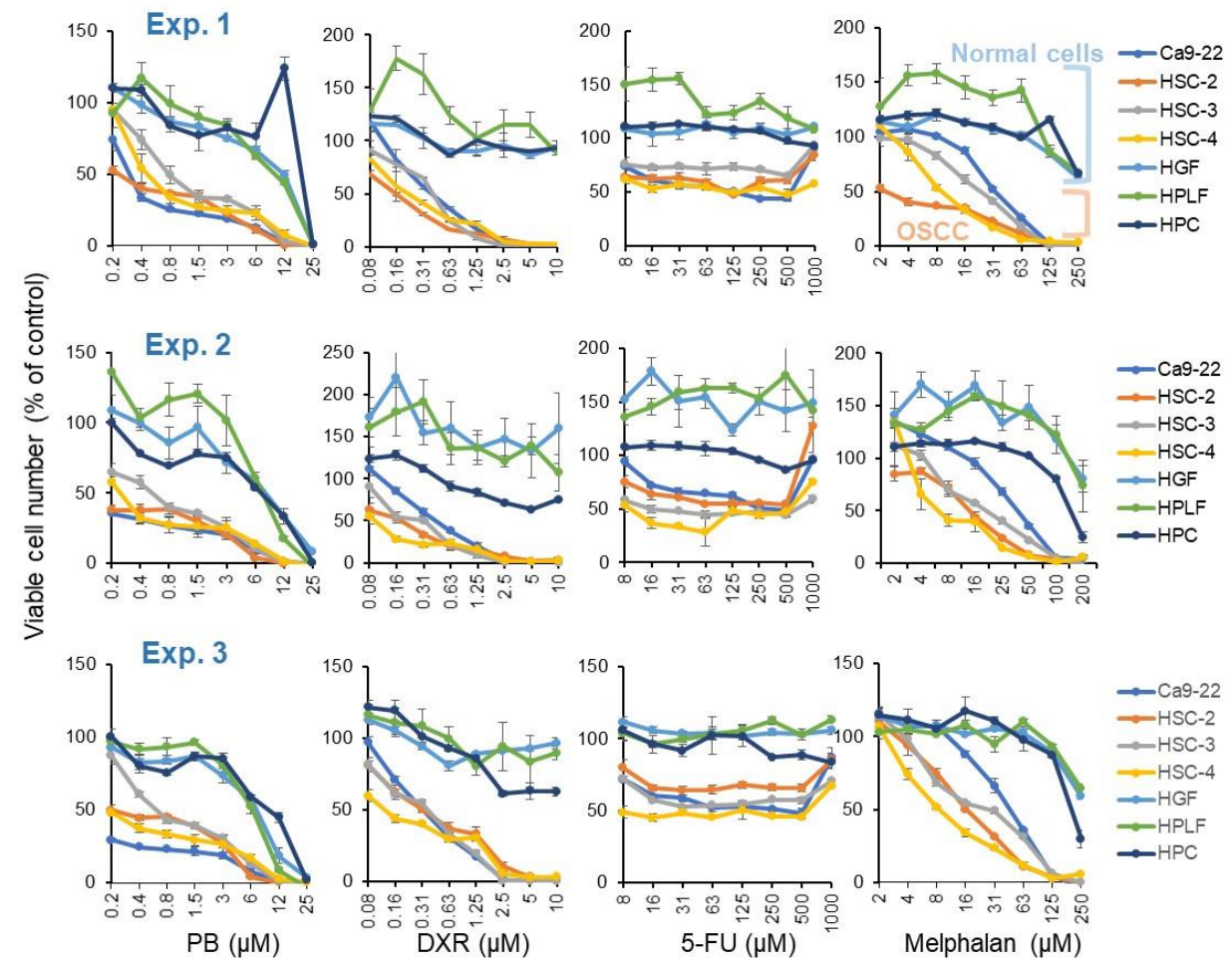

Figure 2. Dose-response curve of cytotoxicity of pyoktanin (PB) and three anticancer drugs (DXR, 5-FU and melphalan). Cells were incubated for $48 \mathrm{~h}$ with the indicated concentrations of test compounds. Experiments were repeated three times. Each value in each panel represents mean \pm S.D. of triplicate assays. PB, pyoktanin blue; DXR, doxorubicin; 5-FU, fluorouracil.

\subsection{Western Blot Analysis}

Control and treated Ca9-22 cells at or near confluent phase were collected and lysed, and protein samples of cell lysates $(15 \mu \mathrm{g})$ were applied to SDS-polyacrylamide gel electrophoresis. After electrophoresis, the separated proteins were transferred onto a PVDF filter. The blots were blocked in skim milk and then probed for 120 min with a primary antibody cocktail (1:250) from Apoptosis Western Blot Cocktail kit (purchased from Abcam, Cambridge, UK). The blots were washed, then probed with horseradish peroxidase conjugated secondary antibody cocktail (1:100). Immunoreactivities were determined using 
Amersham ECL Select. Images were acquired using the ChemiDoc MP System and Image Lab 4.1 software (Bio-Rad Laboratories), as described previously [22].

\subsection{Assay for Anti-Human Immunodeficiency Virus (HIV) Activity}

Human T-cell leukemia virus I (HTLV-I)-bearing CD4-positive human T-cell line MT-4 [23] was cultured in RPMI-1640 medium supplemented with $10 \%$ FBS and infected with HIV- $1_{\text {IIIB }}$ at a multiplicity of infection (MOI) of 0.01 . HIV- and mock-infected MT-4 cells $\left(3 \times 10^{4}\right.$ cells/96-microwell) were incubated for five days with different concentrations of samples in triplicate, and the relative viable cell number was determined by MTT assay, as described previously [24]. Under this condition, cell viability of HIV-infected cells reached to nearly $0 \%$ (baseline). Thus, the concentration that reduced the viable cell number of the mock-infected cells to $50 \%$ of untreated control cells $\left(\mathrm{CC}_{50}\right)$ and the concentration that recovered the viable cell number of the HIV-infected cells to $50 \%$ of the control cells from the baseline $\left(\mathrm{EC}_{50}\right)$ were determined from the dose-response curve. The anti-HIV activity was evaluated by the selectivity index (SI), calculated using the following equation: $\mathrm{SI}=\mathrm{CC}_{50} / \mathrm{EC}_{50}$.

\subsection{Assay for Anti-Herpes Simplex Virus (HSV) Activity}

HSV-1 strain F was cultured in MEM supplemented with 10\% FBS. Anti-HSV activity was measured by method 3, as described previously [24]. In brief, $100 \times \mathrm{HSV}(\mathrm{MOI}=1)$ was exposed to serially diluted PB for $3 \mathrm{~min}$, diluted $\times 100$ to bring MOI $=0.01$, added to African green monkey kidney Vero cells, and then incubated for 3 days. Mock-infected Vero cells were treated for $3 \mathrm{~min}$ with the serially diluted PB for $3 \mathrm{~min}$, washed, and then incubated for 3 days. The relative viable cell number was determined by the MTT method. From the dose-response curve, $50 \%$ cytotoxic concentration $\left(\mathrm{CC}_{50}\right)$ in mock-infected cells and the $50 \%$ effective concentration $\left(\mathrm{EC}_{50}\right.$ ) in HSV-infected cells were determined. Since HSV-infection did not reduce the viability to zero \%, two values of $\mathrm{EC}_{50}$ were determined. $\mathrm{EC}_{50} \mathrm{I} \mathrm{I}$ was determined as the concentration at which the viability was restored to the midpoint between that of HSV-infected cells and that of mock-infected cells. $\mathrm{EC}_{50}$-II was determined as the concentration at which the viability was restored to $50 \%$ of that of the mock-infected cells. The anti-HSV activity was evaluated by the following selectivity indices (SI-I and SI-II): SI-I $=\mathrm{CC}_{50} / \mathrm{EC}_{50}-\mathrm{I}$; SI-II $=\mathrm{CC}_{50} / \mathrm{EC}_{50}$-II [24].

\subsection{Statistical Treatment}

Each value represents the mean \pm S.D. of triplicate assays. Significance between control and sample was evaluated by one-way analysis of variance (ANOVA) for multiple comparisons.

\section{Results}

\subsection{Tumor-Specificity of Pyokanin (PB)}

Pyoktanin (PB), doxorubicin (DXR), and melphalan were cytotoxic, reducing the cell viability to baseline $(0 \%)$, while 5 -FU was cytostatic against four human oral squamous cell carcinoma (OSCC) cell lines (Ca9-22, HSC-2, HSC-3, HSC-4), not completely killing out the cells. All of them showed higher cytotoxicity against four OSCC cell lines than three normal oral cells (HGF, HPLF, HPC). These data were reproducible in three independent experiments (Figure 2). From the dose-response curve, 50\% cytotoxic concentration $\left(\mathrm{CC}_{50}\right)$, tumor-specificity $\left(\mathrm{TS}=\right.$ mean $\mathrm{CC}_{50}$ (normal cells) $/$ mean $\mathrm{CC}_{50}$ (OSCC)), and potency-selectivity expression $\left(\left(\mathrm{PSE}=100 \times \mathrm{TS} /\right.\right.$ mean $\left.\mathrm{CC}_{50}(\mathrm{OSCC})\right)$ were calculated (Table 1$)$. PB showed TS and PSE values $((30.8+26.6+25.4) / 3=27.6$ and $(6722+9203+8067) / 3=7997)$ slightly lower than those of doxorubicin $((30.0+40.7+33.5) / 3=34.7$ and $(9986+16,525+11,192) / 3=12,568)$ but much higher than $5-\mathrm{FU}((3.1+3.0+1.8) / 3=2.6$ and $(0.9+0.9+0.3) / 3=0.7)$ and melphalan $((11.8+10.3+9.4) / 3=10.5$ and $(70+57+46) / 3=58)$.

Next, tumor-specificity was investigated with Ca9-22 and HGF cells, both prepared from gingival tissue. This time, PB showed TS and PSE values $((40.0+43.5+37.9) / 3=40.5$ 
and $(13,197+22,734+19,850) / 3=18,594)$ slightly higher than those of doxorubicin $((24.4+22.1+29.9) / 3=25.5$ and $(5930+4902+8964) / 3=6599)$ but much higher than those of 5 -FU $((8.1+3.2+7.4) / 3=6.2$ and $(6.5+1.0+5.4) / 3=4.3)$ and melphalan $((7.4+5.2+5.2) / 3=5.9$ and $(27+13+14) / 3=18)($ Table 1$)$.

PB induced cell shrinkage (A), caspase-3 activation (assessed by cleavage of procaspase 3 and PARP) (B), and subG1 accumulation (C) to a similar or slightly lower extent than that attained by actinomycin D (Figure 3). These results suggest the induction of apoptosis by pyoktanin. However, such an effect of $\mathrm{PB}$ only became significant $(p<0.05$, vs. control, ANOVA) at $2.2 \mu \mathrm{M}$ but not at $0.74 \mu \mathrm{M}$, indicating the optimal range of apoptosis is very narrow.
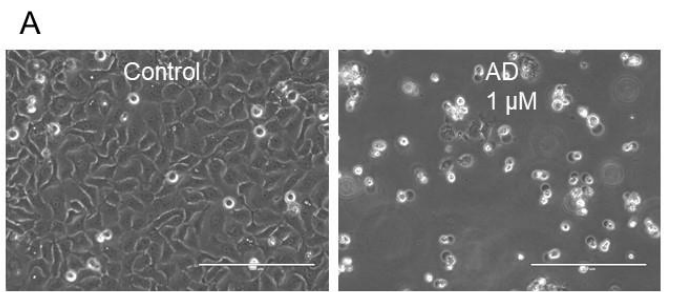

B
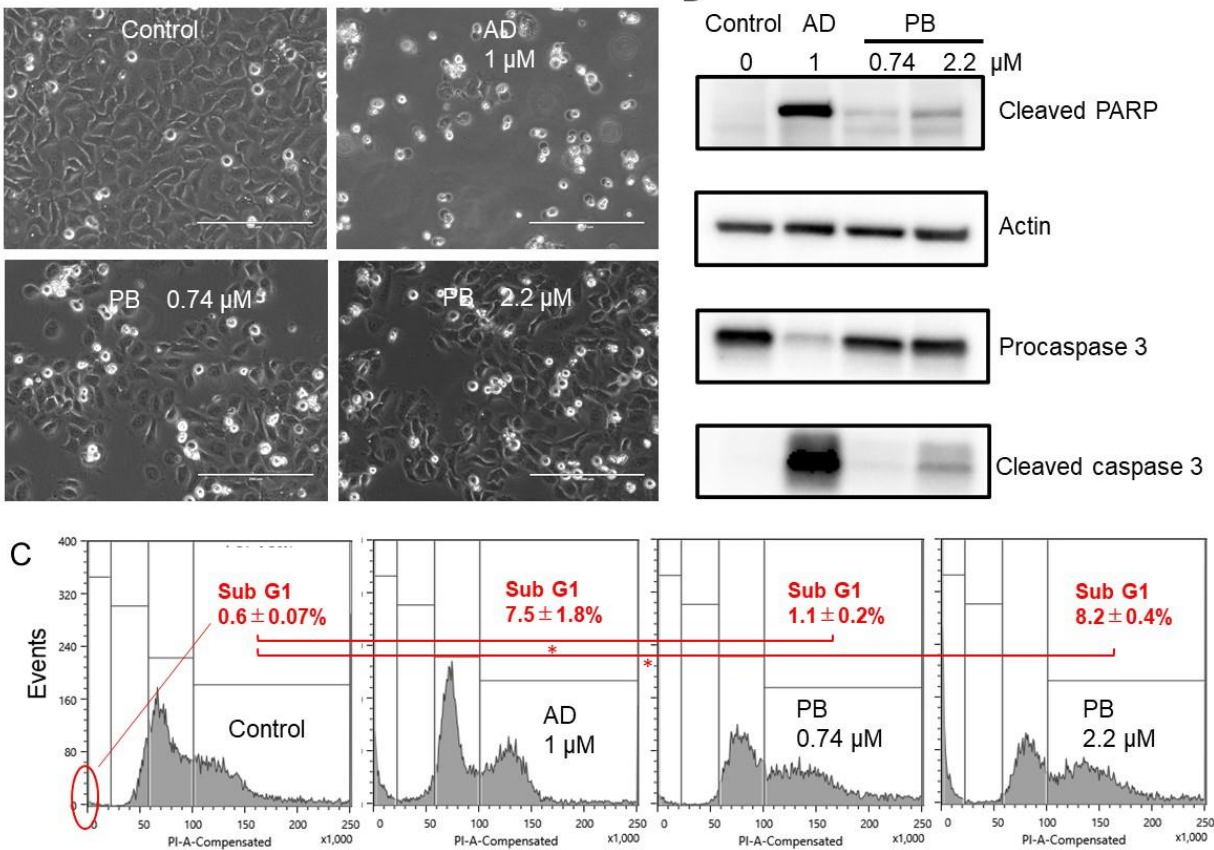

Figure 3. Pyoktanin (PB) induces apoptosis in Ca9-22 cells. Ca9-22 cells were incubated for $24 \mathrm{~h}$ and then subjected to morphological observation under the light microscopy (A), Western blot analysis (B), and cell sorter analysis (C). The percentage of subG1 population was determined in triplicate and expressed as mean \pm S.D. AD, actinomycin $\mathrm{D} ;{ }^{*}$ statistically significant difference from control $(p<0.05)$.

\subsection{Potent Neurotoxicity of $P B$}

Micromolar concentration of PB and DXR induced potent cytotoxicity against both undifferentiated (rat adrenal pheochromocytoma PC12, human neuroblastoma SH-SY5Y) (Figure 4A) and differentiated neuronal cells (PC12) with extended neurites [19] (Figure 4B). On the other hand, neurotoxicity of 5-FU and melphalan were observed at higher concentrations. From the dose-response curve of Figure 4 , the $\mathrm{CC}_{50}$ value of $\mathrm{PB}$ and anticancer drugs were determined (Table 2). It is clear that PB was more cytotoxic to all neuronal cells, either undifferentiated $\left(\mathrm{CC}_{50}=0.179,0.162,0.132 \mu \mathrm{M}\right)$ or differentiated $\left(\mathrm{CC}_{50}=0.252 \mu \mathrm{M}\right)$ than OSCC $\left(\mathrm{CC}_{50}=0.36 \mu \mathrm{M}\right)$. By dividing the $\mathrm{CC}_{50}(\mathrm{OSCC})$ by the mean $\mathrm{CC}_{50}$ (neuronal cells), PB was found to show approximately 2.0-fold higher cytotoxicity against neuronal cells than OSCC. Similarly, DXR, 5-FU and melphalan showed approximately 1.8-, 3.6-, and 1.4-fold higher cytotoxicity against neuronal cells than OSCC (Table 2). 


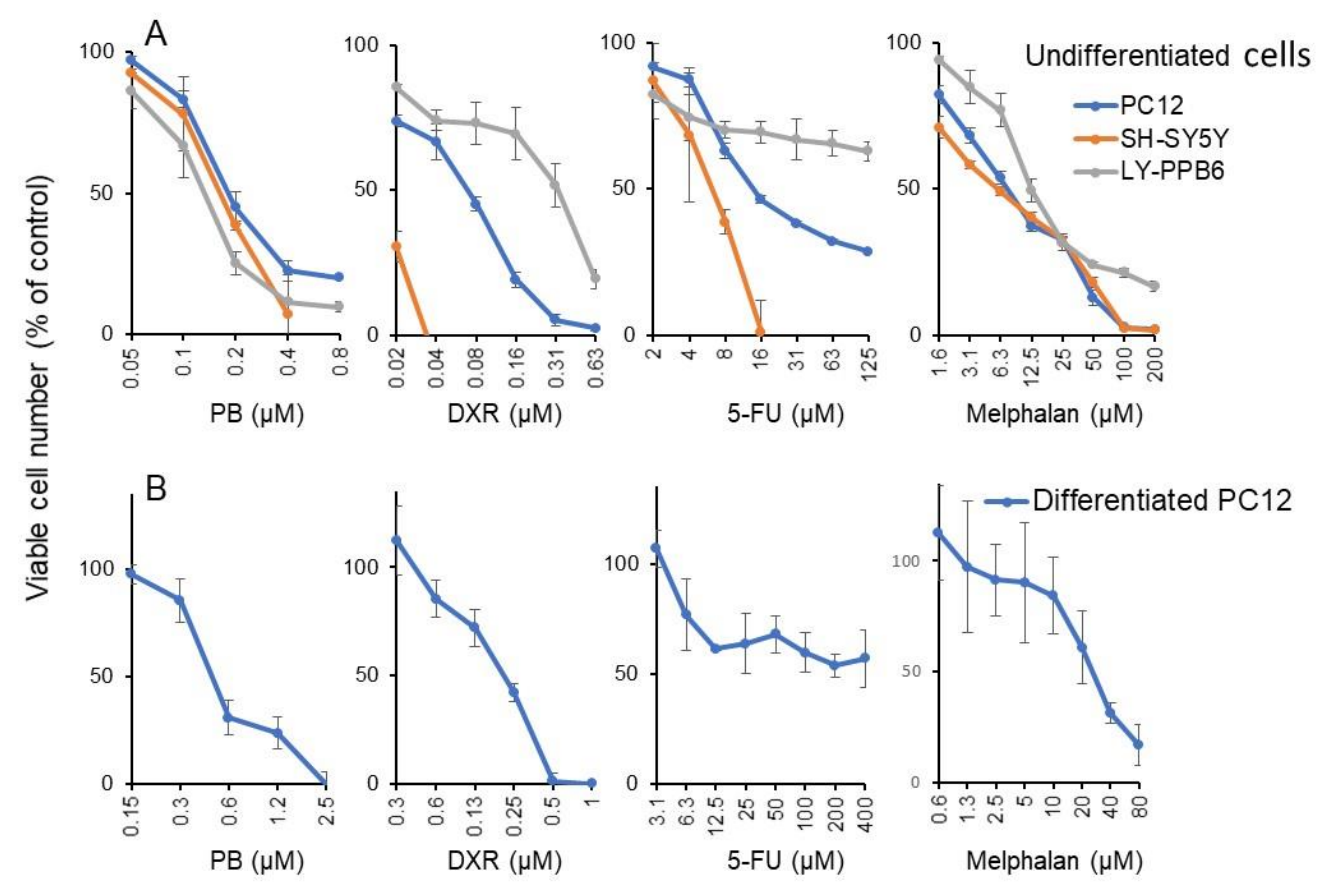

Figure 4. Cytotoxicity of PB and anticancer drugs against PC12, SH-SY5Y, and LY-PPB6 (A) and differentiated PC12 cells (B). Each value represents mean \pm S.D. of triplicate assays.

Table 2. PB and anticancer drugs were more toxic to neuronal cells than OSCC cell lines.

\begin{tabular}{|c|c|c|c|c|c|c|c|}
\hline & \multicolumn{7}{|c|}{$\mathrm{CC}_{50}(\mu \mathrm{M})$} \\
\hline & \multicolumn{4}{|c|}{ Neuronal Cells } & \multirow[b]{2}{*}{ Mean } & \multirow[b]{2}{*}{ OSCC } & \multirow[b]{2}{*}{ Neurotoxicity } \\
\hline & PC12 & SH-SY5Y & LY-PPB6 & Diff.PC-12 & & & \\
\hline & & & & & $\mathrm{E}$ & B & $\mathrm{B} / \mathrm{E}$ \\
\hline PB & 0.179 & 0.162 & 0.132 & 0.252 & $0.181^{1}$ & $0.36^{2}$ & 2.0 \\
\hline DXR & 0.069 & 0.02 & 0.323 & 0.215 & 0.157 & 0.28 & 1.8 \\
\hline 5-FU & 14 & 5.85 & 125 & 297 & 110 & 401 & 3.6 \\
\hline Melphalan & 7.72 & 5.89 & 12.3 & 26.4 & 13.1 & 18.3 & 1.4 \\
\hline
\end{tabular}

${ }_{1}$ determined from Figure $4 .{ }^{2}$ mean of three experiments, calculated from Table 1.

\subsection{Re-Evaluation of Antiviral Activity of PB}

3.3.1. Pyoktanin (PB) failed to induce anti-HIV activity

Pyoktanin was highly cytotoxic to the MT-4 cell line, a target cell used for measuring anti-HIV activity. Its cytotoxicity was detectable above $0.31 \mu \mathrm{M}$. HIV infection (MOI) reduced the viability of MT- 4 to zero. PB recovered the cell viability only to $15.7 \%$ (A), whereas inhibitors of HIV's reverse transcriptase such as AZT (B) and ddC (C) as well as sulfated polysaccharides such as dextran sulfate (D) and curdlan sulfate (E) recovered the cell viability up to $85.1,68.7,91.0$, and $111.3 \%$ of control, respectively (Figure 5).

From the dose-response curve of mock-infected and HIV-infected cells, 50\% cytotoxic concentration $\left(\mathrm{CC}_{50}\right)$ and $50 \%$ protective concentration $\left(\mathrm{EC}_{50}\right)$ were determined, respectively. Anti-HIV activity was quantitated by the selective index (SI), calculated by dividing $\mathrm{CC}_{50}$ by $\mathrm{EC}_{50}$ (Table 3). It was found that $\mathrm{PB}$ did not show detectable anti-HIV activity $(\mathrm{SI}<1)$, in contrast to AZT $(\mathrm{SI}=5082)$, ddC $(\mathrm{SI}=1340)$, dextran sulfate $(\mathrm{SI}=4200)$, and curdlan sulfate (SI > 5294). 

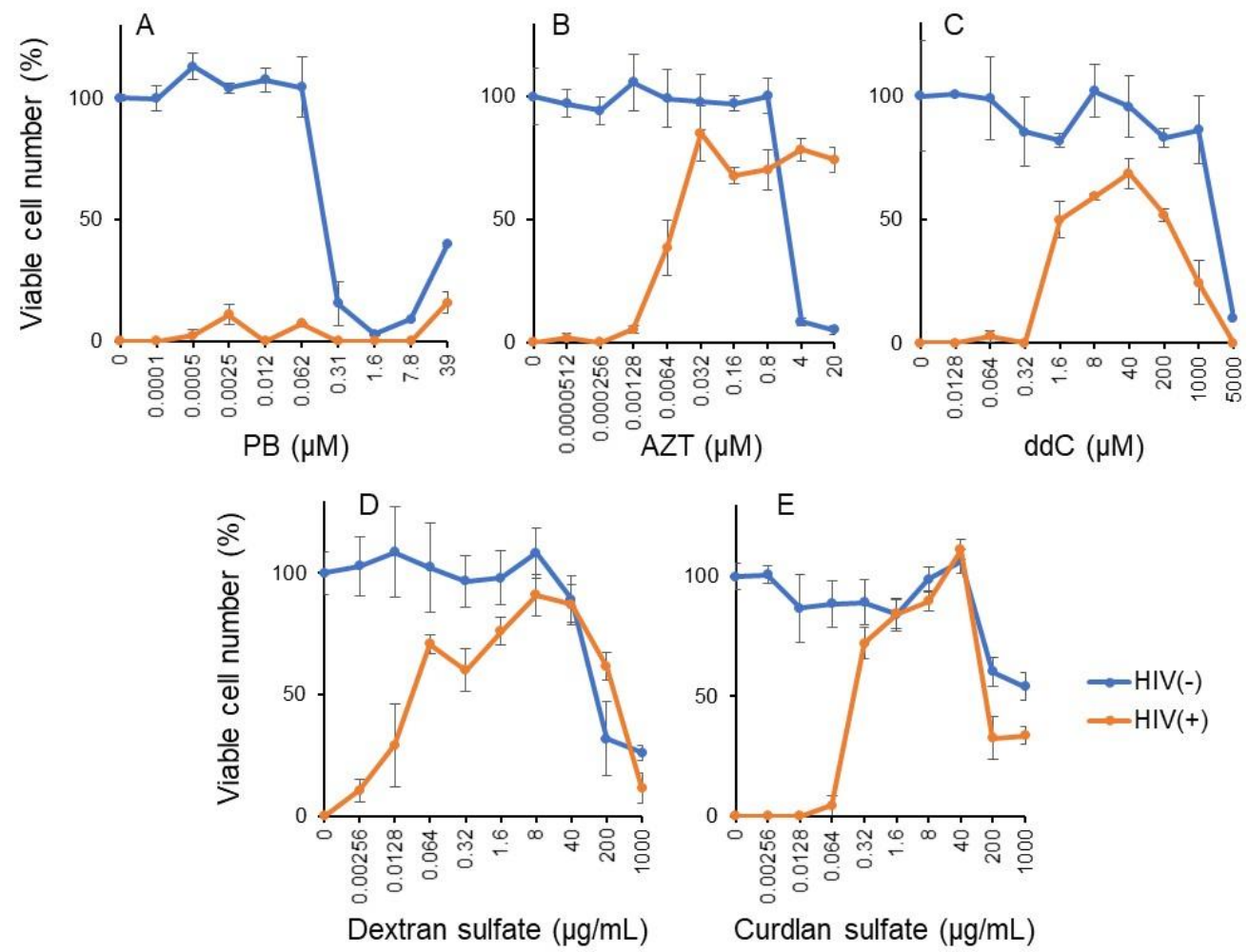

Figure 5. PB failed to induce anti-HIV activity. Mock and HIV-infected MT-4 were treated with the indicated concentrations of pyoktanin (A), AZT (B), ddC (C), dextran sulfate (D), and curdlan sulfate (E) for 5 days to determine the viability by MTT method. Each value represents mean \pm S.D. of triplicate assay.

Table 3. Quantification of anti-HIV activity of pyoktanin.

\begin{tabular}{cccc}
\hline & $\mathrm{CC}_{50}(\mu \mathrm{g} / \mathrm{mL})$ & $\mathrm{EC}_{50}(\mu \mathrm{g} / \mathrm{mL})$ & SI \\
\hline PB & $0.168 \mu \mathrm{M}$ & $>39 \mu \mathrm{M}$ & $<1$ \\
Positive controls: & & & 5082 \\
AZT & $48.3 \mu \mathrm{M}$ & $0.0095 \mu \mathrm{M}$ & 1340 \\
ddC & $2163 \mu \mathrm{M}$ & $1.61 \mu \mathrm{M}$ & 4200 \\
Dextran sulfate & $120 \mu \mathrm{g} / \mathrm{mL}$ & $0.0286 \mu \mathrm{g} / \mathrm{mL}$ & $>5294$ \\
Curdlan sulfate & $>1000 \mu \mathrm{g} / \mathrm{mL}$ & $0.189 \mu \mathrm{g} / \mathrm{mL}$ & \\
\hline
\end{tabular}

\subsubsection{Pyoktanin (PB) failed to induce anti-HSV activity}

We recently demonstrated that alkaline extract of leaves of Sasa sp. (SE) rapidly inactivated HSV as well as HIV [24]. Therefore, the anti-HSV activity of PB was next investigated in a short exposure system, using alkaline extract of leaves of Sasa sp. (SE) as positive control [25]. HSV (MOI = 1) was first exposed for $3 \mathrm{~min}$ to the indicated concentrations of PB (A) or SE (B), followed by 100x dilution to bring the MOI to 0.01, and was then added to Vero cells. After incubation for 3 days, the cell viability was reduced to $26 \%(\mathrm{~A})$ and $15.6 \%$ (B) of control (Figure 6$)$. When PB $(0.25-245 \mu \mathrm{M})$ and SE $(0.1-60 \mathrm{mg} / \mathrm{mL})$ were added during a short exposure time, only SE (A) but not PB (B) recovered the cell viability above control (Figure 6). 

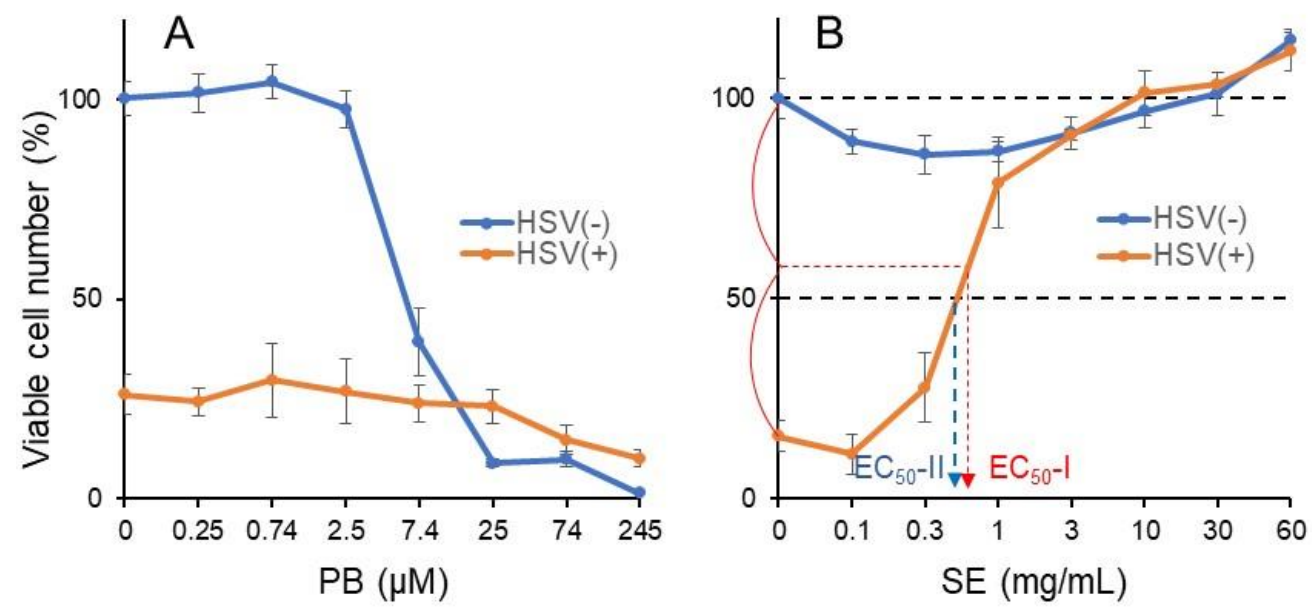

Figure 6. PB failed to induce anti-HSV activity. 100xHSV $(\mathrm{MOI}=1)$ and the indicated concentrations of PB (A) or SE (B) were mixed for $3 \mathrm{~min}$, diluted to $\mathrm{x} 100$ with culture medium to bring $\mathrm{MOI}=0.01$, added to Vero cells, and then incubated for 3 days (HSV(+)). Mock-infected Vero cells were treated for $3 \mathrm{~min}$ with the indicated concentrations of sample without virus, washed, and cultured for 3 days in fresh culture medium (HSV(-)) according to method 3 [24]. Viable cell number was then determined by MTT method. Each value represents mean \pm S.D. of triplicate assay.

From the dose-response curve of mock-infected and HSV-infected cells, 50\% cytotoxic concentration $\left(\mathrm{CC}_{50}\right)$ and $50 \%$ protect concentration $\left(\mathrm{EC}_{50}\right)$ were determined, respectively (Figure 6B). Since HSV infection could not reduce the viability to zero (Figure 6B), in contrast to HIV infection (Figure 5), $\mathrm{EC}_{50}-\mathrm{I}$ and $\mathrm{EC}_{50}-\mathrm{II}$ values were determined. Anti-HSV activity was quantitated by the selective index (SI), calculated by dividing $\mathrm{CC}_{50}$ by $\mathrm{EC}_{50}-\mathrm{I}$ or $\mathrm{EC}_{50}$-II (Table 3). It was found that PB did not show detectable anti-HIV activity (SI-I $<0.02$, SI-II $<0.02$; maximum cell recovery $=29.7 \%)$, in contrast to SE $($ SI-I $>76.9$, SI-II $>89.6$; maximum cell recovery $=101.4 \%$ ) (Table 4$)$.

Table 4. Quantification of anti-HSV activity of pyoktanin.

\begin{tabular}{|c|c|c|c|c|c|c|c|}
\hline \multirow{2}{*}{ Test Sample } & \multirow{2}{*}{$\begin{array}{c}\text { Viability of } \\
\text { HSV-Infected Cells }\end{array}$} & \multirow{2}{*}{$\mathrm{CC}_{50}$} & \multirow{2}{*}{$\mathrm{EC}_{50}-\mathrm{I}$} & \multirow{2}{*}{$\mathrm{EC}_{50}$-II } & \multicolumn{2}{|c|}{ Anti-HSV Activity } & \multirow{2}{*}{$\begin{array}{l}\text { Max. Cell } \\
\text { Recovery }\end{array}$} \\
\hline & & & & & SI-I & SI-II & \\
\hline $\mathrm{PB}$ & $26.0 \%$ & $5.88 \mu \mathrm{M}$ & $>245 \mu \mathrm{M}$ & $>245 \mu \mathrm{M}$ & $<0.02$ & $<0.02$ & $29.7 \%$ \\
\hline SE & $14.2 \%$ & $>60 \mathrm{mg} / \mathrm{mL}$ & $>0.78 \mathrm{mg} / \mathrm{mL}$ & $0.67 \mathrm{mg} / \mathrm{mL}$ & $>76.9$ & $>89.6$ & $101.4 \%$ \\
\hline
\end{tabular}

Selective index (SI-I, SI-II) was determined by dividing $\mathrm{CC}_{50}$ by $\mathrm{EC}_{50}$-I or $\mathrm{EC}_{50}$-II (Figure 6)

\section{Discussion}

We used human OSCC cell lines and human mesenchymal normal oral cells rather using human epithelial cells for determining anticancer activity (based on TS and PSE) since most of anticancer drugs show potent cytotoxicity against epithelial cells. Using the present system, we previously confirmed that many anticancer drugs show excellent TS and PSE values [26,27].

The present study demonstrated that pyoktanin (PB) showed potent anti-cancer activity against four human oral squamous cell carcinoma (OSCC) cell lines. Its tumor-specificity $\left(\mathrm{TS}=27.6(\mathrm{D} / \mathrm{B}), 40.5(\mathrm{C} / \mathrm{A})\right.$; PSE $\left.=7997\left(100 \mathrm{D} / \mathrm{B}^{2}\right), 18,594\left(100 \mathrm{C} / \mathrm{A}^{2}\right)\right)$ was comparable with doxorubicin (TS = 34.7, 25.5; PSE = 12,568, 6599) and much higher than 5-FU (TS = 2.6, 6.2; PSE $=0.7,4.3)$ and melphalan $(\mathrm{TS}=10.5,5.9 ; \mathrm{PSE}=58,18)$.

Furthermore, PB induced apoptotic cell death (characterized by cell shrinkage, caspase3 activation, and subG1 cell accumulation) in the Ca9-22 cell line prepared from gingiva, further adding the antitumor potential of $\mathrm{PB}$. A previous study demonstrated that $\mathrm{PB}$ induced significant cell death in oral precancerous cells via decreased phosphorylation of p53(Ser15) and NFkB (Ser536) in vitro and oral-base-formulated PB effectively suppressed 
the progression of DMBA-induced oral precancerous lesions in vivo [15]. Taken together, PB may be applicable as a therapeutic drug not only for oral malignant disorder but also for OSCC.

Previous studies showed a lower bound on the virtually safe dose (VSD) of PB to be $2 \mathrm{ppb}(4.9 \mathrm{nM})$ for female mice and $1 \mathrm{ppb}(2.45 \mathrm{nM})$ for male mice [28]. Administration of $\mathrm{PB}(600 \mathrm{ppm}=1.47 \mathrm{mM}, 24$ months $)$ induced hepatocellular adenoma at the probability of $4 / 89$, whereas the induction of thyroid gland follicular cell adenoma or adenocarcinoma was rare at 300 600 ppm (0.735 1.47 mM for 24 months) [29]. PB, having $\log \mathrm{P}$ of 4.488, can be easily permeated through the plasma membrane. PB binds to DNA, and together with its cellular toxicity, complicates both the testing of $\mathrm{PB}$ in vitro and the interpretation of the results. PB around $5 \mu \mathrm{M}$ seems to be the borderline of carcinogenicity [29]. This concentration is 1 order higher than that of $\mathrm{CC}_{50}$ of PB for four OSCC cell lines (Figure 2).

The present study also demonstrated that $\mathrm{PB}$ induced potent neurotoxicity at nearly half the concentration required to inhibit OSCC growth (Figure 4). We found that PB inhibited the neurite outgrowth, in similar fashion to bortezomib (1 ng/mL) [20], X-ray (506 mGy) [30], paclitaxel (5 nM) [31], and $A \beta_{1-42}(20 \mathrm{nM})$ [32]. We also found that during the differentiation of $\mathrm{PC} 12$ toward maturing neuronal cells, the sensitivity against $\mathrm{PB}, \mathrm{DXR}$, 5-FU, and melphalan was reduced 1.4- $(=0.252 / 0.179), 3.1-(=0.215 / 0.069), 21.2-(=297 / 14)$, and 3.4-fold (26.4/7.72), respectively (Table 2). This is consistent with our previous finding that the sensitivity of PC12 cells toward docetaxel, SN-38 (active component of irinotecan), etoposide, gefinitib, DXR, melphalan, 5-FU, and methotrexate was reduced to various extents (maximum: 10,000-fold) during NGF-induced differentiation [33]. Chemotherapyinduced peripheral neuropathy (CIPN) is not recovered from quickly by a drug withdrawal, and some disorders may remain for a lifetime. The incidence of CIPN 1,3, and 6 months after chemotherapy is reported to be $68.1,60.0$, and $30.0 \%$, respectively [34]. Platinum, taxane, and vinca alkaloid are known as causative agents of CIPN. Cisplatin is cumulative and causes sensorineural deafness in the high range due to acoustic nerve damage [35]. The incidence of oral mucositis has been reported to be $5-50 \%$ among patients receiving standard-dose chemotherapy and 68-98\% among patients receiving high-dose chemotherapy for hematopoietic stem cell transplantation [36]. Painful oral mucositis lowers the patient's QOL, and oral intake of nutrition and may trigger systemic infection by breaking the gateway function of oral mucosa. At present, there are no established preventive or curative methods for oral mucositis [37]. When cytotoxic chemotherapy drugs are accidentally leaked at the injection site, they can cause multiple emergencies by local and systemic reactions $[38,39]$. Vesicants such as doxorubicin (classified as anthracycline) and melphalan (classified as alkylating agent) bind to DNA and induce the formation of blisters and/or cause tissue destruction, while irritants such as 5-FU (classified as antimetabolite) can cause pain at the injection site or along the vein [17]. Considering the high incidence of side effects of anticancer drugs, it is necessary to investigate the extent to which PB induces oral stomatitis and extravasation in comparison with anticancer drugs. Our preliminary experiment demonstrated that the cytotoxic action of $\mathrm{PB}$ was so quick that shortening the exposure time up to 2 min dramatically reduced the cytotoxicity of PB against HGF and HPLF (Supplementary Materials Figure S1). For clinical application, such countermeasures may be effective.

Oral squamous cell carcinoma (OSCC) is the most common malignant tumor of the oral cavity. Human papilloma virus (HPV) has been proposed as a risk factor in OSCC development. Epstein-Barr virus and HSV Type 1 have been proposed to be involved in oral carcinogenesis, albeit in the absence of convincing evidence [40]. HIV could play a role in HPV-associated pathogenesis by exerting oncogenic stimulus via transactivator protein (Tat) [41]. Therefore, we thought if PB were to inhibit HSV and HIV, PB treatment might be efficacious in reducing the incidence of OSCC. In contrast to previous papers that demonstrated the antiviral potential of PB $[13,14]$, we failed to show anti-HIV and anti-HSV activity in this study. The reason for the discrepancy between our findings and 
theirs may be differences in the type of viruses, culture conditions, or calculation method of the chemotherapy index.

In conclusion, the present study demonstrated that $\mathrm{PB}$ induces potent antitumor activity against OSCC (as evidenced by TS and PSE value, almost equivalent with those of anticancer drugs), in addition to its antibacterial, antifungal, antihelminthic, and antitrypanosomal activities. However, PB also showed higher neurotoxicity against three neuronal cells, either undifferentiated or differentiated. We previously reported the tumor-specificity $\left(\mathrm{TS}=10.4(\mathrm{D} / \mathrm{B})+4.6(\mathrm{C} / \mathrm{A})=15 ; \mathrm{PSE}=1551\left(100 \mathrm{D} / \mathrm{B}^{2}\right)+246\left(100 \mathrm{C} / \mathrm{A}^{2}\right)=1797\right)[27]$ and neurotoxicity of cisplatin $(\mathrm{B} / \mathrm{E}=0.73 / 4.4=0.17)$ [20]. Compared with these values, the tumor-specificity of PB $(\mathrm{TS}=30.8+40.0=70.8 ;$ PSE $=6722+13197=19917)($ Table 1$)$ was 4.7-fold (70.8/15) 11.1-fold (19919/1797) that of cisplatin. On the other hand, the neurotoxicity of $\mathrm{PB}(\mathrm{B} / \mathrm{E}=2.0)$ was 11.8 -fold that of cisplatin $(\mathrm{B} / \mathrm{E}=4.4 / 0.73=0.17)$. This further supports the notion that $\mathrm{PB}$ is first-class as both an anticancer drug and a neurotoxic agent, with these two activities tightly coupled.

Considering its carcinogenicity by interaction with DNA, the combination of PB with appropriate photodynamic therapy may be the safest clinical application in the oral cavity.

Supplementary Materials: The following is available online at https:/ /www.mdpi.com/article/10 $.3390 /$ medicines8070033/s1, Figure S1: Rapid cytotoxic action of PB.

Author Contributions: Conceptualization, formal analysis, investigation and funding acquisition, H.S., K.F., T.K. (Takuro Koshikawa), D.A.; Methodology, H.S., K.S., S.A., Y.I., T.K. (Takuro Koshikawa), D.A.; Writing—original draft preparation, H.S.; Writing—review and editing, H.S., T.F., H.T., T.K. (Taisei Kanamoto); Supervision, H.S. and S.Y.; Project administration, T.F. All authors have read and agreed to the published version of the manuscript.

Funding: This research was funded by KAKENHI from the Japan Society for the Promotion of Science (JSPS) (No. 20K09885) (H.S.); the Showa University Graduate School Research Fund (K.F.); and the Meikai University Miyata Research Fund B (H.S.).

Institutional Review Board Statement: Ethical review and approval were waived for this study since we used only cultured cells that had been purchased from the RIKEN Cell Bank and the cells established in our laboratory 11 years ago according to the guidelines of the intramural Ethics Committee (No. A0808).

Informed Consent Statement: Not applicable since we used only cultured cells.

Data Availability Statement: We provide our unpublished data in support of our findings in Supplementary Materials Figure S1.

Acknowledgments: The authors thank Daiwa Biological Research Institute Co., Ltd. for providing SE. We acknowledge Shigemi Terakubo for technical support for the anti-HIV assay.

Conflicts of Interest: The authors declare no conflict of interest.

\section{References}

1. Ghanadan, A.; Kamyab-Hesari, K.; Daneshpajouh, M.; Balighi, K.; Normohammadpour, P. Nodular colloid degeneration of the skin: Report of three cases with review and update. Indian Dermatol. Online J. 2014, 5, S36-S39. [CrossRef] [PubMed]

2. Hayashi, N.; Sasaki, T.; Tomura, N.; Okada, H.; Kuwata, T. Removal of a malignant cystic brain tumor utilizing pyoktanin blue and fibrin glue: Technical note. Surg. Neurol. Int. 2017, 8, 24. [CrossRef]

3. Otani, N.; Wada, K.; Toyooka, T.; Takeuchi, S.; Tomiyama, A.; Mori, K. Usefulness of dural surface tracing of the cortical vessels with indocyanine green videoangiography just prior to dural opening for various cerebrovascular diseases. Surg. Neurol. Int. 2017, 8, 201. [CrossRef] [PubMed]

4. Takamiya, S.; Seki, T.; Yamazaki, K.; Sasamori, T.; Houkin, K. Intraoperative Visualization of a Spinal Arachnoid Cyst Using Pyoktanin Blue. World Neurosurg. 2018, 109, 18-23. [CrossRef] [PubMed]

5. Tripathi, N.; Sapra, A. Gram Staining. In StatPearls, StatPearls Publishing Copyright @ 2021; StatPearls Publishing LLC.: Treasure Island, FL, USA, 2021.

6. Churchman, J.W. The Selective Bactericidal Action of Gentian Violet. J. Exp. Med. 1912, 16, 221-247. [CrossRef] [PubMed]

7. Gomes-de-Elvas, A.R.; Palmeira-de-Oliveira, A.; Gaspar, C.; Gouveia, P.; Palmeira-de-Oliveira, R.; Pina-Vaz, C.; Rodrigues, A.G.; Martinez-de-Oliveira, J. In vitro assessment of gentian violet anti- candida activity. Gynecol. Obs. Investig. 2012, 74, 120-124. [CrossRef] [PubMed] 
8. Masuda, Y.; Sakagami, H.; Horiike, M.; Kadokura, H.; Yamasaki, T.; Klokkevold, P.R.; Takei, H.H.; Yokose, S. Photodynamic Therapy with Pyoktanin Blue and Diode Laser for Elimination of Enterococcus faecalis. In Vivo 2018, 32, 707-712. [CrossRef] [PubMed]

9. Akhtar, F.; Khan, A.U.; Misba, L.; Akhtar, K.; Ali, A. Antimicrobial and antibiofilm photodynamic therapy against vancomycin resistant Staphylococcus aureus (VRSA) induced infection in vitro and in vivo. Eur. J. Pharm. Biopharm. 2021, 160, 65-76. [CrossRef] [PubMed]

10. Soares, R.B.; Costa, D.H.; Miyakawa, W.; Delgado, M.G.T.; Garcez, A.S.; Yoshimura, T.M.; Ribeiro, M.S.; Nunez, S.C. Photodynamic Activity on Biofilm in Endotracheal Tubes of Patients Admitted to an Intensive Care Unit. Photochem. Photobiol. 2020, 96, 618-624. [CrossRef]

11. Kazuno, K.; Kinoshita, H.; Hori, M.; Yosizaki, T.; Tamura, A.; Sato, H.; Murata, S. Endovascular treatment for mycotic aneurysm using pyoktanin- applied devices. CVIR Endovasc. 2020, 3, 55. [CrossRef] [PubMed]

12. Maley, A.M.; Arbiser, J.L. Gentian violet: A 19th century drug re-emerges in the 21st century. Exp. Derm. 2013, 22, 775-780. [CrossRef] [PubMed]

13. Aljofan, M.; Sganga, M.L.; Lo, M.K.; Rootes, C.L.; Porotto, M.; Meyer, A.G.; Saubern, S.; Moscona, A.; Mungall, B.A. Antiviral activity of gliotoxin, gentian violet and brilliant green against Nipah and Hendra virus in vitro. Virol. J. 2009, 6, 187. [CrossRef] [PubMed]

14. Nagayama, A. Inactivation of influenza A virus by gentian violet (GV) and GV-dyed cotton cloth, and bactericidal activities of these agents. J. Infect. Chemother. 2006, 12, 73-79. [CrossRef] [PubMed]

15. Wang, Y.Y.; Xiao, L.Y.; Wu, P.C.; Chen, Y.K.; Lo, S.; Hu, S.C.S.; Chen, Y.H.; Chiu, C.C.C.; Yuan, S.S.F. Orabase-formulated gentian violet effectively improved oral potentially malignant disorder in vitro and in vivo. Biochem. Pharm. 2020, 171, 113713. [CrossRef] [PubMed]

16. Yamaguchi, M.; Vikulina, T.; Weitzmann, M.N. Gentian violet inhibits MDA-MB-231 human breast cancer cell proliferation, and reverses the stimulation of osteoclastogenesis and suppression of osteoblast activity induced by cancer cells. Oncol. Rep. 2015, 34, 2156-2162. [CrossRef] [PubMed]

17. Sugita, Y.; Takao, K.; Uesawa, Y.; Nagai, J.; Iijima, Y.; Sano, M.; Sakagami, H. Development of Newly Synthesized Chromone Derivatives with High Tumor Specificity against Human Oral Squamous Cell Carcinoma. Medicines 2020, 7, 50. [CrossRef] [PubMed]

18. Kantoh, K.; Ono, M.; Nakamura, Y.; Nakamura, Y.; Hashimoto, K.; Sakagami, H.; Wakabayashi, H. Hormetic and anti-radiation effects of tropolone-related compounds. In Vivo 2010, 24, 843-851. [PubMed]

19. Sakagami, H.; Shi, H.; Bandow, K.; Tomomura, M.; Tomomura, A.; Horiuchi, M.; Fujisawa, T.; Oizumi, T. Search of Neuroprotective Polyphenols Using the "Overlay" Isolation Method. Molecules 2018, 23, 1840. [CrossRef]

20. Iijima, Y.; Bandow, K.; Amano, S.; Sano, M.; Hino, S.; Kaneko, T.; Horie, N.; Sakagami, H. Protection of Bortezomib-induced Neurotoxicity by Antioxidants. Anticancer Res 2020, 40, 3685-3696. [CrossRef] [PubMed]

21. Horikoshi, M.; Kimura, Y.; Nagura, H.; Ono, T.; Ito, H. A new human cell line derived from human carcinoma of the gingiva. I. Its establishment and morphological studies. Nihon Koku Geka Gakkai Zasshi 1974, 20, 100-106. [CrossRef] [PubMed]

22. Yamali, C.; Sakagami, H.; Uesawa, Y.; Kurosaki, K.; Satoh, K.; Masuda, Y.; Yokose, S.; Ece, A.; Bua, S.; Angeli, A.; et al. Comprehensive study on potent and selective carbonic anhydrase inhibitors: Synthesis, bioactivities and molecular modelling studies of 4-(3-(2-arylidenehydrazine-1-carbonyl)-5-(thiophen-2-yl)-1H-pyrazole-1-yl) benzenesulfonamides. Eur. J. Med. Chem. 2021, 217, 113351. [CrossRef]

23. Miyoshi, I.; TAGUCHI, H.; Kubonishi, I.; Yoshimoto, S.; Ohtsuki, Y.; Shiraishi, Y.; Akagi, T. Type C virus-producing cell lines derived from adult T cell leukemia. Gann Monogr. Cancer Res. 1982, 28, 219-229.

24. Fukuchi, K.; Sakagami, H.; Sugita, Y.; Takao, K.; Asai, D.; Terakubo, S.; Takemura, H.; Ohno, H.; Horiuchi, M.; Suguro, M.; et al. Quantification of the Ability of Natural Products to Prevent Herpes Virus Infection. Medicines 2020, 7, 64. [CrossRef]

25. Sakagami, H.; Fukuchi, K.; Kanamoto, T.; Terakubo, S.; Nakashima, H.; Natori, T.; Suguro-Kitajima, M.; Oizumi, H.; Yasui, T.; Oizumi, T. Synergism of Alkaline Extract of the Leaves of Sasa senanensis Rehder and Antiviral Agents. In Vivo 2016, 30, 421-426.

26. Sakagami, H.; Okudaira, N.; Masuda, Y.; Amano, O.; Yokose, S.; Kanda, Y.; Suguro, M.; Natori, T.; Oizumi, H.; Oizumi, T. Induction of Apoptosis in Human Oral Keratinocyte by Doxorubicin. Anticancer Res. 2017, 37, 1023-1029. [CrossRef] [PubMed]

27. Iijima, Y.; Bandow, K.; Sano, M.; Hino, S.; Kaneko, T.; Horie, N.; Sakagami, H. In Vitro Assessment of Antitumor Potential and Combination Effect of Classical and Molecular-targeted Anticancer Drugs. Anticancer Res. 2019, 39, 6673-6684. [CrossRef] [PubMed]

28. Littlefield, N.A.; Blackwell, B.N.; Hewitt, C.C.; Gaylor, D.W. Chronic toxicity and carcinogenicity studies of gentian violet in mice. Fundam. Appl. Toxicol. 1985, 5, 902-912. [CrossRef]

29. Meng Sun, K.R.; Gwendolyn Osborne, M.; Marder, E.; Schmitz, R. Proposition 65 Evidence on the Carcinogenicity of Gentian Violet; Branch, R.a.C.H.A., Ed.; Office of Environmental Health Hazard, Assessment California Environmental Protection Agency: Sacramento, CA, USA, 2018.

30. Nakaya, G.; Sakagami, H.; Koga-Ogawa, Y.; Shiroto, A.; Nobesawa, T.; Ueda, D.; Nakatani, S.; Kobata, K.; Iijima, Y.; Tone, S.; et al. Augmentation of Neurotoxicity of Anticancer Drugs by X-ray Irradiation. In Vivo 2020, 34, 1009-1016. [CrossRef] [PubMed]

31. Hara, Y.; Sakagami, H.; Shi, H.; Abe, T.; Tamura, N.; Takeshima, H.; Horie, N.; Kaneko, T.; Shiratsuchi, H.; Kaneko, T. Partial Protection of Paclitaxel-induced Neurotoxicity by Antioxidants. In Vivo 2018, 32, 745-752. [CrossRef] [PubMed] 
32. Sakagami, H.; Tsuji, M.; Tomomura, M.; Masuda, Y.; Iwama, S.; Nakagawa, M.; Suzuki, H.; Tanaka, K.; Abe, T.; Tamura, N.; et al. Protection of Differentiating Neuronal Cells from Amyloid $\beta$ Peptide-induced Injury by Alkaline Extract of Leaves of Sasa senanensis Rehder. In Vivo 2018, 32, 231-239. [CrossRef]

33. Sakagami, H.; Hara, Y.; Shi, H.; Iwama, S.; Nakagawa, M.; Suzuki, H.; Tanaka, K.; Abe, T.; Tamura, N.; Takeshima, H.; et al. Change in Anticancer Drug Sensitivity During Neuronal Differentiation of PC12 Cells. In Vivo 2018, 32, 765-770. [CrossRef] [PubMed]

34. Seretny, M.; Currie, G.L.; Sena, E.S.; Ramnarine, S.; Grant, R.; MacLeod, M.R.; Colvin, L.A.; Fallon, M. Incidence, prevalence, and predictors of chemotherapy-induced peripheral neuropathy: A systematic review and meta-analysis. Pain 2014, 155, 2461-2470. [CrossRef] [PubMed]

35. Mollman, J.E.; Hogan, W.M.; Glover, D.J.; McCluskey, L.F. Unusual presentation of cis-platinum neuropathy. Neurology 1988, 38 , 488-490. [CrossRef] [PubMed]

36. Bellm, L.A.; Epstein, J.B.; Rose-Ped, A.; Martin, P.; Fuchs, H.J. Patient reports of complications of bone marrow transplantation. Support. Care Cancer 2000, 8, 33-39. [CrossRef]

37. Vera-Llonch, M.; Oster, G.; Ford, C.M.; Lu, J.; Sonis, S. Oral mucositis and outcomes of allogeneic hematopoietic stem-cell transplantation in patients with hematologic malignancies. Support. Care Cancer 2007, 15, 491-496. [CrossRef]

38. Harrold, K.; Gould, D.; Drey, N. The management of cytotoxic chemotherapy extravasation: A systematic review of the literature to evaluate the evidence underpinning contemporary practice. Eur. J. Cancer Care 2015, 24, 771-800. [CrossRef]

39. Kreidieh, F.Y.; Moukadem, H.A.; El Saghir, N.S. Overview, prevention and management of chemotherapy extravasation. World J. Clin. Oncol. 2016, 7, 87-97. [CrossRef]

40. Sand, L.; Jalouli, J. Viruses and oral cancer. Is there a link? Microbes Infect. 2014, 16, 371-378. [CrossRef]

41. Kim, R.H.; Yochim, J.M.; Kang, M.K.; Shin, K.H.; Christensen, R.; Park, N.H. HIV-1 Tat enhances replicative potential of human oral keratinocytes harboring HPV-16 genome. Int. J. Oncol. 2008, 33, 777-782. [PubMed] 